\title{
Efektivitas Pembelajaran Berbasis Riset pada Mata Kuliah Hikmat al-Tasyri'
}

\author{
Muhammad Muhsin Arumawan \\ Universitas Islam Negeri (UIN) Maulana Malik Ibrahim Malang \\ Email: muhsinarumawan@pai.uin-malang.ac.id \\ Hayyun Lathifaty Yasri \\ Universitas Islam Negeri (UIN) Maulana Malik Ibrahim Malang \\ Email: hayyunlathifah@pips.uin-malang.ac.id \\ Received: July 18, 2020 | Accepted: December 8, 2020
}

\begin{abstract}
Research-based learning is a learning approach that can stimulate critical thinking skills and improve learning outcomes. In line with this, this study aims to determine the effectiveness of research-based learning in the Hikmatu-t-Tasyri 'lecture. This research was conducted using qualitative methods with a period of 6 months. The data collection techniques used were observation, distributing questionnaires and using supporting documentation. The collected data is then processed through data reduction, data display and conclusion drawing. The results of this study indicate that the implementation of research-based learning in the Hikmatu-tTasyri 'course is proven to be good. This is evidenced by the results of distributing questionnaires regarding student assessments of the effectiveness of research-based learning with the 5 indicators mentioned above which obtained an average result in the Good category.
\end{abstract}

\begin{abstract}
Abstrak
Pembelajaran berbasis riset merupakan salah satu pendekatan pembelajarn yang dapat menstimulus kemampuan berpikir kritis serta meningkatkan hasil belajar. Selaras dengan hal tersebut, penelitian ini bertujuan untuk mengetahui efektivitas pembelajaran berbasis riset dalam perkuliahan Hik'mat al-Tasyri'. Penelitian ini dilaksanakan dengan metode kualitatif dengan masa 6 bulan. Teknik pengambilan data yang digunakan ialah observasi, penyebaran angket dan pemanfaatan dokumentasi pendukung. Data yang terkumpul selanjutnya diolah melalui reduksi data, display data dan penarikan kesimpulan. Hasil penelitian ini menunjukkan bahwa pelaksanaan pembelajaran berbasis riset pada mata kuliah Hik'mat al-Tasyri' terbukti baik. Hal ini terbukti dengan hasil penyebaran angket mengenai penilaian mahasiswa terhadap efektivitas pembelajaran berbasis riset denga 5 indikator tersebut di atas yang memperoleh hasil rata-rata kategori Baik.
\end{abstract}

\section{Keywords}

Teaching and learning effectivity, reasearch based learning, Hik'mat al-Tasyri' 


\section{Pendahuluan}

Dalam pelaksanaan pendidikan, hal utama yang menjadi acuan ialah adanya tujuan pendidikan yang jelas yang hendak dicapai melalui kegiatan tersebut. Ketercapaian tujuan pendidikan menjadi sebuah indikator efektivitas pembelajaran di samping indikator-indikator yang lainnya. Sebuah kegiatan pembelajaran dapat dikatakan efektif dan berkualitas jika pembelajaran tersebut memperhatikan inputnya yang terdiri dari perencanaan pembelajaran, pendidik, peserta didik, sarana dan prasarana serta masyarakat. Selain memperhatikan bebrapa hal tersebut, pembelajaran efektif dapat terwujud dengan hasil pembelajaran yang dicapai oleh peserta didik, bukan hanya pada aspek kognitif, afektif, dan psikomor saja, namun juga lingkungan yang sehat, kurikulum yang relevan, serta peserta didik yang sehat dan fokus dalam pembelajaran (Setyosari, 2014:29) . Hal itu sesuai dengan tujuan pendidikan yang tertuang di dalam Undang - Undang No. 20 tahun 2003 tentang sistem pendidikan nasional yang menyatakan Pendidikan Nasional bertujuan untuk berkembangnya potensi peserta didik agar menjadi manusia yang beriman dan bertakwa kepada Tuhan Yang Maha Esa, berakhlak mulia, sehat, berilmu. cakap, kreatif, mandiri, dan menjadi warga negara yang demokratis serta bertanggung jawab (UU Sisdiknas No. 20 Tahun 2003). Dalam mewujudkan pembelajaran yang efektif diperlukan adanya sinergitas antara faktor-faktor pendukung yang terdiri dari lingkungan belajar, fasilitas belajar, satana prasarana, keahlian guru serta kerjasama antara pendidik dan peserta didik yang baik (Fakhrurrazi, 2018: 97). Selanjutnya, Yusuf (2017: 13) menyebutkan efektivitas pembelajaran dapat dinilai melalui beberapa indikator yaitu: pengelolaan pelaksanaan pembelajaran yang baik, 2) proses pembelajaran yang komunikatif, 3) respon peserta didik yang positif, 4) aktifitas belajar, dan 5) ketercapaian hasil belajar.

Pembelajaran yang efektif juga menekankan pada penggunaan pendekatan komunikatif, yaitu pendekatan yang bertujuan untuk meningkatkan ketrampilan peserta didik dalam berkomunikasi, menekankan pengembangan dan pembinaan kemampuan komunikatif peserta didik. Pendekatan komunikatif dalam pembelajaran dilakukan sepenuhnya oleh peserta didik, guru ataupun pendidikan berperan sebagai fasilitator dalam pembelaharan. Dengan demikian kemampuan peserta didik dalam menyampaikan pemahaman serta pengetahuan dan pendapatnya baik dalam bentuk pertanyaan, jawaban, kritikan, penambahan maupun sanggahan, bisa berupa penyampaian tertulis maupun penyampaian lisan langsung (Laily, 2015: 3 - 4). Oleh karena itu hendaknya bagi pengajar/dosen menyampaikan tujuan-tujuan pembelajaran dan motitivasi belajar di awal pembelajaran, sehingga pada akhir pembelajaran mahasiswa dapat memantau perkembangan keterampilan, sikap dan pengetahuannya secara mandiri. Dengan demikian, mahasiswa mampu mengukur ketercapaian tujuan pembelajaran melalui hasil belajarnya.

Menurut Wahyuningsih (2020: 65) hasil belajar merupakan kemampuan yang dimiliki peserta didik sebagai hasil dari kegiatan pembelajaran yang telah diikuti, dapat juga diartikan bahwa hasil belajar merupakan kemampuan yang dimiliki peserta didik seteleh mereka menerima pengalaman belajar dalam proses pembelajaran yang dilaluinya. Menurut Bloom dalam taksonominya hasil belajar memiliki tiga ranah diantaranya; 1) ranah kognitif, yang mencakup ingatan atau pengenalan terhadap fakta-fakta tertentu, pola-pola prosedural, dan konsep-konsep yang memungkinkan berkembangnya kemampuan dan intelektual (Huda, 2013: 2), 2) ranah afektif, ranah yang berkaitan dengan perkembangan perasaan, sikap, nilai dan emosi; 3) ranah psikomotor, ranah yang berkaitan dengan kegiatan-kegiatan manipulatif atau ketrampilan motorik (Degeng, 2013:202). 
Berdasarkan hasil observasi pra penelitian di UIN Maulana Malik Ibrahim Malang Jurusan PAI kelas I pada pembelajaran Hikmatut Tasyri' ditemukan beberapa fakta dalam proses belajar mengajar, diantaranya: (1) mahasiswa tampak jenuh, bosan dan mengantuk, (2) respon mahasiswa kurang aktif, (3) mahasiswa kurang menyimak pelajaran. Proses pembelajaran yang berlangsung cenderung dikuasai oleh pengajar/dosen dan minimnya pelibatan mahasiswa di dalamnya. Sehingga menyebabkan kurang kondusifnya aktivitas pembelajaran di kelas (Observasi 2020).

Hal yang dapat dilakukan untuk menindaklanjuti permasalahan di atas salah satunya ialah dengan menerapkan pembelajaran berbasis riset. Hal ini dapat dilakukan dengan pemanfaatan jurnal ilmiah yang relevan untuk kepentingan kegiatan pembelajaran. Salah satu keunggulan penggunaan jurnla-jurnal ilmiah daripada buku teks ialah jurnal ilmiah memiliki kebaruan konsep dan teori, waktu publikasi yang relatif baru, adanya proses review dalam penulisannya, serta inspirasi penulisan yang banyak diilhami oleh masalah-masalah faktual (Arif B P, 2017: 18). Pelaksanan pembelajaran berbasis riset memiliki berbagai manfaat bagi peserta didik, di antaranya ialah membantu peserta didik mengembangkan kemampuan berfikir kritisnya serta meningkatkan hasil belajarnya. Hal ini sebagaimana temuan Slameto (2015: 102) yang menunjukkan bahwa pelaksanaan kegiatan pembelajaran berbasis riset terbukti mampu meningkatkan hasil belajar peserta didik setidaknya $8 \%$ hingga 35\%, dengan rata-rata peningkatan $18,45 \%$.

\section{Metode}

Mengacu pada tujuan penelitian ini, maka dalam upaya pencapainnya, maka penelitian ini dilaksanakan dengan metode kualitatif deskriptif. Pada penelitian kualitatif, intrumen utama yang sangat berpengaruh pada kualitas data yang diperoleh ialah peneliti itu sendiri. Data pada penelitian ini dikumpulkan melalui kegiatan observasi, penyebaran angket dan dokumentasi. Observasi yang digunakan merupakan observasi partisipasif, sedangkan angket yang digunakan merupakan angket tertutup. Kegiatan observasi dilakukan untuk menggali data mengenai pelaksanaan kegiatan pembelajaran berbasis riset, sedangkan angket digunakan untuk menggali data mengenai efektivitas pembelajaran, dan dokumentasi digunakan dalam menggalian data hasil belajar sebagai salah satu indikator efektivitas pembelajaran. Indikator efektivitas pembelajaran yang digunakan dalam penelitian ini mengacu pada Yusuf (2017: 13) yang terdiri dari: 1) pengelolaan pelaksanaan pembelajaran yang baik, 2) proses pembelajaran yang komunikatif, 3) respon peserta didik yang positif, 4) aktifitas belajar, dan 5) ketercapaian hasil belajar. Sumberdata dalam penelitian ini ialah sumberdata primer dan sumber data skunder. Sumber data primer dalam penelitian ini ialah mahasiswa Jurusan PAI kelas I, sedangkan sumber data skundernya ialah dokumen pendukung penelitian baik berupa jurnal, buku, ataupun artikel lainnya. Penelitian ini dilaksanakan selama enam bulan, yaitu pada bulan Januari - Mei 2019 pada pembelajaran mata kuliah Hikmatut Tasyri' Jurusan Pendidikan Agama Islam (PAI) UIN Maulana Malik Ibrahim Malang. Data yang telah terkumpul selanjutnya direduksi untuk mengidentifikasi dan memilah-milah data yang memang dibutuhka dan sesuai dengan tujuan penelitian dengan yang tidak. Setelah proses reduksi data, selanjutnya data disajikan dalam bentuk pembahsan dan ilustrasi tabel. Terakhir, berdasarkan penyajian data, maka hasil penelitian dapat disimpulkan. 


\section{Hasil dan Pembahasan}

Pembelajaran berbasis riset merupakan bnetuk praktik pembelajaran yang autenteik, kooperatif, berbasis pemecahan masalah, kontekstual yang menggukan pendekatan pendekatan inkuiri berdasarkan filsafat konstruktivisme. Pembelajaran berbasis riset memberikan sumbangsiih nyata dalam mesntimulus dan mengembangkan kemampuan peserta didik dalam melakukan penelitian (Rangkuti, 2016: 150). Temuan ini memperkuat temuan Prahmana \& Darhim (2016:12) yang menyatakan bahwa sintaks model pembelajaran berbasis riset sangat berperan dalam menumbuhkan keterampilan meneliti masing-masing peserta didik. Pembelajaran berbasis riset dapat dilakukan dengan pendekatan Problem Based Learning, Inquiry, dan juga Contextual Teaching and Learning yang dapat diwujudkan dalam bentuk diskusi, simulasi, praktik, permainan, ceramah interaktif bahkan debat (Firmadani, 2017:267).

Pada pra pelaksanaan pembelajaran berbasis riset, di awal semester dosen menyampaikan sistematika pembelajarannya. Dimulai dengan pembagian seluruh menjadi beberapa kelompok yang kemudian masing-masing kelompok diberikan satu tema untuk dibahas. Pola pembahasan tema dalam pembelajaran berbasis riset dilaksanakan dengan memanfaatkan literatur-literatur ilmiah sebagai sumber belajar. Dosen menyampaikan teknis pelaksanaannya yang terdiri dari: 1) penelusuran literatur ilmiah sebagai sumber belajar, pada tahap ini dosen memberikan batasan minimum artikel ilmiah yang digunakan sebanyak 2 jurnal ilmiah dengan tanpa batasan maksimum. 2) Selanjutny literratur ilmiah didiskusikan oleh masing-masing kelompok berdasarkan analisis konten yang relevan dengan topik pembahasan yang dimiliki. 3) Hasil diskusi dan analisis kelompok kemudian dikonsultasikan kepada dosen pengampu matakuliah sebelum akhirnya dipresentasikan di depan kelas. 4) tehakhir ialah proses presentasi hasil analisis dan hasil diskusi disampaikan di depan kelas. 5) Setelah penyampaian materi, dibuka sesi tanya jawab untuk mahasiswa lainnya. 6) Berikutnya adalah tambahan dan klarifikasi dari dosen yang dilanjutkan dengan penutupan.

Pelaksanaan pembelajaran berbasis riset pada penelitian ini dimulai dengan kegiatan pendahuluan. Pada kegiatan pendahuluan, dosen membuka pertemuan dengan do'a dan mukadimah. Dalam mukadimah dosen memberikan sedikit ulasan tentang materi minggu lalu dan juga memberikan pengantar tentang tema yang akan dibahas. Selain itu dosen menyampaikan manfaat dan tujuan mempelajari materi pada pertemuan tersebut. Hal terakhir yang disampaikan dosen adalah memberikan motivasi bagi mahasiswa untuk belajar. Setelah penyampaian hal - hal tersebut dosen memberikan waktu kepada para mahasiswa untuk berdiskusi dengan sistem yang telah disepakai dan ditentukan.

Kegiatan selanjutnya adalah pelaksanaan pembelajaran berbasis riset. Pada kegiatan ini mahasiswa yang telah ditetapkan sebagai pemateri dipersilakan untuk mempresentasikan jurnal -jurnal yang relevan dengan tema pembahasan yang telah dipilihnya. Pemilihan jurnal - jurnal itu dilakukan oleh pemateri jauh hari sebelum jadwal mereka untuk presentasi. Para pemateri tidak hanya memilih jurnal tetapi juga mengkonsultasikan jurnal -jurnal yang telah dipilihnya kepada dosen pengampu matakuliah. Hal itu dilakukan untuk menghindari kesalahan dalam pemilihan jurnal. Dalam diskusi yang dilaksanakan juga diberikan waktu untuk dosen untuk menyampaikan tentang materi yang didiskusikan. Hal ini bertujuan agar tidak terjadi kesalahan dalam materi yang didiskusikan. Oleh karena itu, sebuah keharusan bagi seorang dosen untuk menguasai materi, memberikan ilustrasi yang jelas, dan juga memberikan keleluasaan bagi mahasiswa untuk menyampaikan pertannyaan selanjutnya dosen memberi tanggapan atas pertannyaan mahasiswa dengan baik. Selain tanya jawab, mahasiswa juga diberikan kesempatan 
untuk mengajukan kritik dan saran jika ada. Hal yang tidak kalah penting yang harus diperhatikan oleh dosen dan mahasiswa adalah menyelesaikan waktu yang telah ditetapkan.

Kegiatan terakhir adalah Penutup. Kegiatan ini mencakup empat hal, 1) Dosen memberikan kesimpulan di akhir pembelajaran 2) dosen memberikan penugasan kepada mahasiswa secara umum sekaligus untk mempersiapkan mahasiswa mengkuti perkuliahan minggu berikutnya 3) Dosen memberikan kesempatan bertanya tentang tugas yang diberikan 4) Dosen memberikan motivasi dan pesan-pesan untuk menstimulus semangat belajar mahasiswa, dan 5) menutup pembelajaran dengan doa dan salam.

Hasil penelitian ini menunjukkan bahwa pelaksanaan pembelajaran berbasis riset pada matakuliah Hik'mat al-Tasyri' terbukti efektif. Hal ini sebagaimana ditemukan bahwa rata-rata mahasiswa menilai bahwa indikator-indikator pembelajaran efektif telah terpenuhi. Di samping itu, efektivitas juga tampak dari tercapainya tujuan pembelajaran yang terbukti dari kelulusan seluruh mahasiswa pada matakuliah ini dengan rata-rata nilai pada kategori Baik atau B. Untuk memperjelas hasil dari penelitian ini, berikut pembahasannya hasil penelitiannya.

\section{Efektivitas Pembelajaran Berbasis Riset}

Dalam pembelajaran, efektivitas dapat dicapai melalui keterampilan guru mengelola pembelajaran dalam dimensi utuh. Terdapat tiga ranah dalam dimensi utuh yang harus dipenuhi guru jika hendak mewujudkan pembelajaran efektif, yaitu dimensi penyampaian, dimensi substansi dan dimensi situasi. Pada dimensi penyampaian, efektivitas pembelajaran dapat dicapai ketika guru mampu melibatkan peserta didik secara aktif dalam kegiatan pembelajaran dengan cakupan seluas dan sedalam mungkin. Pada dimensi substansi, efektivitas pembelajaran dapat dicapai ketika guru mampu memberikan stimulus yang optimal bagi peserta didik sehingga mereka dapat mengembangkan keterampilan berfikir kontekstualnya. Sedangkan dalam dimensi situasi, efektivitas pembelajaran dapat dicapai ketika guru dapat mengelola kelas sehingga situasinya menyenangkan (Sembiring, 2008: 97-98)

Berdasarkan hasil analisis pada masing-masing indikator pembelajaran efektif, ditemukan hasil sebagaimana berikut:

\section{Pengelolaan Pelaksanaan Pembelajaran}

Pengelolaan kelas merupakan upaya guru dalam menciptakan kegiatan pemebalajaran yang berkualitas dan efektif bagi peserta didiknya. Pengelolaan kelas ini meliputi pengelolaan terhadap perencanaan pembelajaran, pengaturan dan pengoptimalan berbagai sumber belajar, serta bahan dan sarana pembelajaran yang dapat membantu terciptanya pembelajaran yang efektif dan berkualitas (Widiasworo 2018,13). Menurut Sanjaya dalam Marasabessy $(2012,8)$ Pengelolaan Pembelajaran adalah sebuah kegiatan yang dilakukan untuk mengendalikan aktifitas pembelajaran yang didasarkan pada prinsip dan konsep pembelajaran demi mencapai tujuan yang telah ditetapkan. Dengan demikian, dapat disimpulkan bahwa pengelolaan pembelajaran adalah suatu proses yang dilaksanakan oleh dosen dan mahasiswa dalam situasi edukatif untuk mencapai tujuan tertentu yang telah ditetapkan.

Berdasarkan hasil olah data penelitian, diketahui bahwa pengelolaan pelaksanaan pembelajaran berbasis riset yang dilakukan oleh pengajar/dosen mendapat respon baik dari mahasiswa. Hal ini terbukti dari 12 sub indikator yang digunakan sebagai alat ukur, 57\% mahasiswa menyatakan bahwa pengelolaan pembelajaran tergolong baik. Selebihnya, sebanyak $36 \%$ mahasiswa menyatakan sangat baik dan 7\% mahasiswa menyatakan kurang baik. Dengan 
demikian, secara umum, dapat disimpulkan bahwa rata-rata mahasiswa mengakui bahwa pengelolaan pelaksanaan pembelajaran berbasis riset telah memenuhi kategori baik. Untuk memperjelas uraian tersebut, berikut dilampirkan adalah diagram lingkarannya:

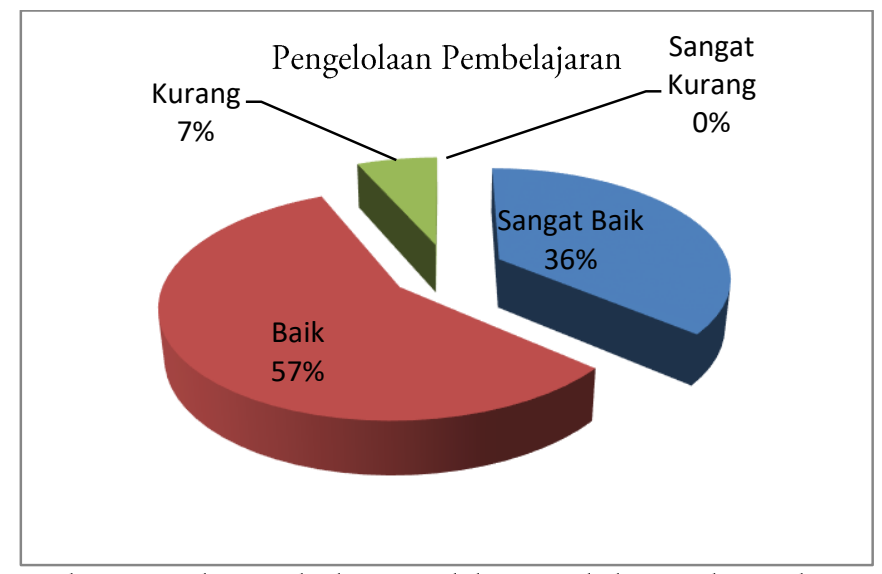

Gambar 1. Penilaian terhadap Pengelolaan Pembelajaran dari Mahasiswa

\section{Proses Belajar Mengajar Komunikatif}

Pembelajaran yang komunikatif menjadi penting karena mampu meningkatkan kemampuan berkomunikasi dan menulis peserta didik. Kemampuan ini merupakan kemampuan yang dibutuhkan dalam menunjang keberhasilan pembelajaran. Harsono (2017: 27) menemukan bahwa penerapan strategi pembelajaran komunikatif mampu meningkatkan hasil belajar peserta didik sampai 5,9\%. Selanjutnya, Suyatna $(2017,9)$ menyatakan bahwa kemampuan berpikir kritis, kreatif, kolaboratif dan komunikatif dapa dikembangkan melalui kegiatan pembelajaran yang berbasis proyek ataupun berbasis masalah. Hasil projek ataupun kajian masalah selanjutnya dikomunikasikan baik secara tertulis maupun lisan.

Pada penelitian ini, pelaksanaan pembelajaran komunikatif dilakukan dengan mengacu pada lima indikator yang telah disampaikan oleh Yusuf (2017: 18).Llima indikator dalam Proses Belajar Mengajar Komunikatif tersebut yaitu, yang pertama dalam pembelajaran komunikatif adalah mengutamakan makna sebenarnya, yang kedua adalah adanya interaksi antara pengajar/dosen dan mahasiswa. Indikator yang ketiga dalam Proses Belajar Mengajar Komunikatif adalah orientasi kompetensi. Selanjutnya indikator keempat ialah menemukan kaidah berbahasa/berkomunikasi dan indikator yang terakhir atau yang kelima adalah Materi ajar bermakna. Berdasarkan perolehan data angket yang diisi oleh subjek penelitian, ditemukan hasil bahwa rata-rata mahasiswa menyatakan bahwa pelaksanaan pembelajaran komunikatif telah dilaksanakan dengan baik. Hal ini sebagaimana dapat dilihat pada diagram lingkaran berikut: 


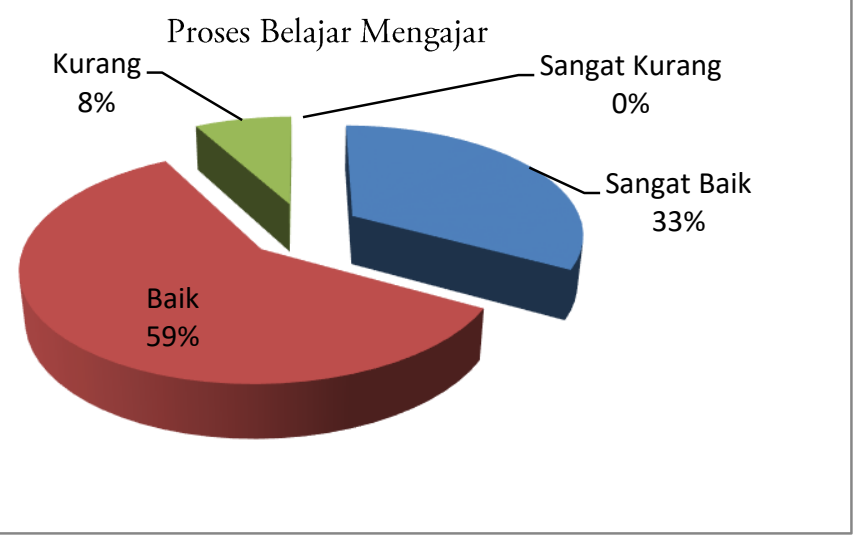

Gambar 2. Penilaian terhadap Proses Belajar Mengajar dari Mahasiswa

Berdasarkan diagram di atas, dapat diketahui bahwa $8 \%$ mahasiswa menilai bahwa kegiatan pembelajaran kurang komunikatif. Selanjutnya ditemukan 59\% mahasiswa menyatakan pelaksanaan pembelajaran komunikatif tergolong baik, dan 33\% mahasiswa menyatakan sangat baik. Dengan demikian dapat disimpulkan bahwa mahasiswa menilai proses belajar mengajar terlaksanan dengan baik.

\section{Respon Peserta Didik/Mahasiswa}

Berdasarkan hasil penelitian ada enam indikator dalam respon peserta didik terhadap efktifitas pembelajaran yaitu, yang pertama adalah perhatian, Indikator yang kedua adalah Antusiasme. Indikator yang ketiga dalam respon peserta didik terhadap efktifitas pembelajaran adalah Rasa. Indikator keempat Kepuasan. Indikator yang kelima dalam respon peserta didik terhadap efktifitas pembelajaran adalah Keingintahuan. Indikator yang terakhir atau yang keenam dalam respon peserta didik terhadap efktifitas pembelajaran adalah Senang. Dari keenam indikator dalam kategori respon peserta didik tersebut diperoleh hasil sebagai berikut:

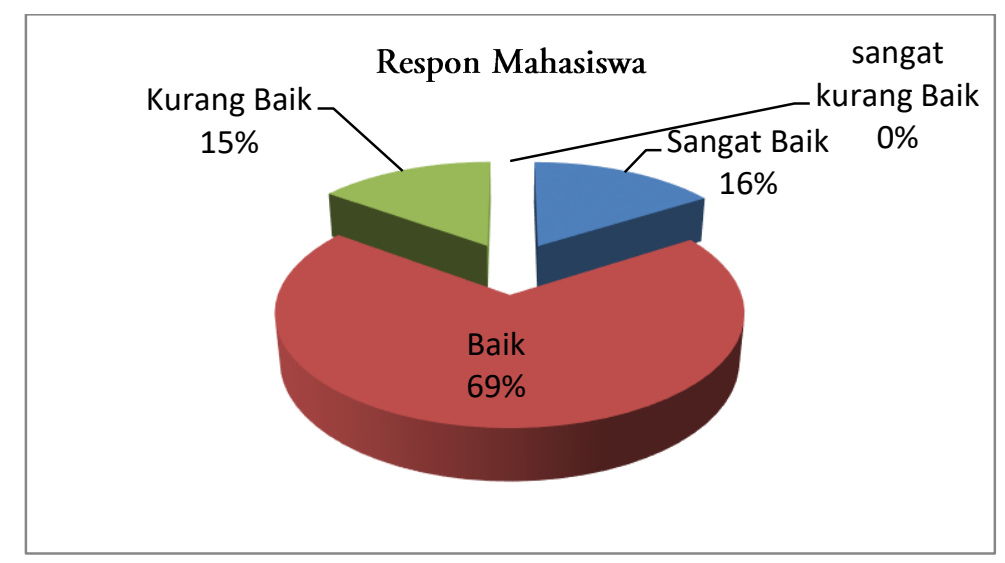

Gambar 3. Respon Mahasiswa dalam Pembelajaran 
Berdasarkan diagram lingkaran di atas, dapat diketahui bahwa bahwa rata-rata respon mahasiswa terhadap kegiatan pembelajaran masuk pada kategori baik dengan persentase sebesar $69 \%$. Sedangkan mahasiswa yang merespon kegiatan pembelajaran dengan sangat baim sekitar $16 \%$, dan mahasiswa yang merespon buruk adalah 15\%. Dengan demikian dapat dinyatan bahwa ditinjau dari respon mahasiswa, kegiatan pembelajaran berbasis riset ik untuk dilakukan.

\section{Aktivitas Belajar}

Dalam pembelajaran, peserta didik membutuhkan kesempatan untuk dapat melakukan sebuah aktivitas. Aktivitas belajar dapat terjadi dalam satu konteks perencanaan untuk mencapai satu tujuan teretentu. Dalam aktivitas belajar, peserta didik menggunakan seluruh potensi yang dimiliki untuk belajar sehingga terjadi adanya perubahan perilaku. Aktivitas belajar dapat terjadi dengan ciri-ciri tertentu, yaitu dilakukan secara sadar, bersifat positif, fungsional dan aktif, bersifat permanen atau tidak sementara, terarah dan memiliki tujuan tertentu dan mencakup seluruh aspek tingkah laku secara utuh (Rusman, 2017: 90).

Berdasarkan pendapat di atas, dapat disimpulkan bahwa aktivitas belajar adalah kegiatan yang dilakukan peserta didik atau peserta didik dalam proses belajarnya secara sadar, terarah, fungsional dan bertujuan untuk mewujudkan adanya perubahan tingkah laku. Menurut Yusuf (2017: 19) ada enam indikator dalam Aktivitas Belajar yaitu, (1) Kegiatan mental (2) Kegiatan mendengarkan (3) Kegiatan visual (4) Kegiatan menulis (5) Kegiatan lisan (6) Kegiatan emosional. Dari keenam indikator tersebut, efektivitas pembelajaran ditinjau dari aktivitas belajar mahasiswa memperoleh penilaian sebagai berikut:

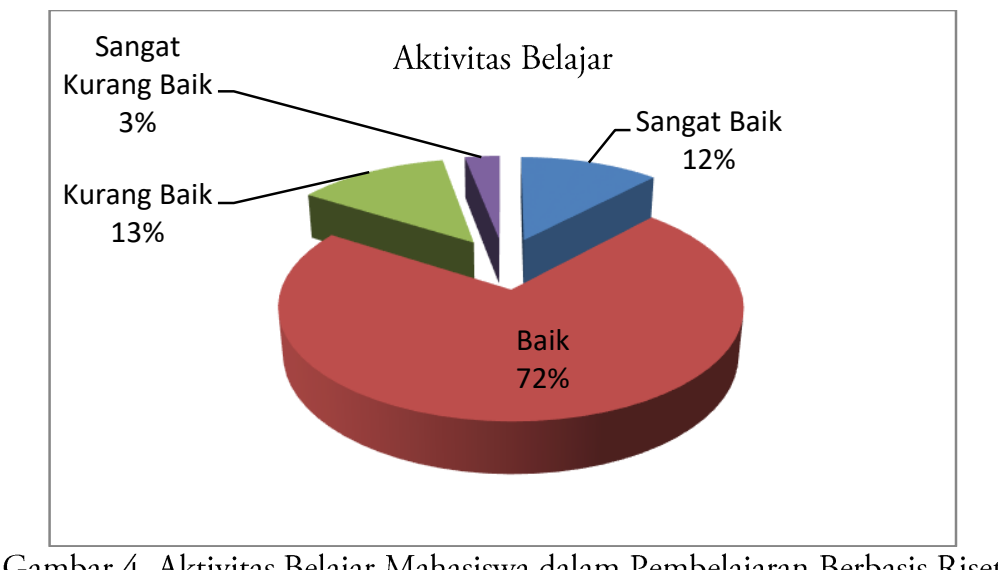

Berdasarkan diagram lingkaran di atas, dapat diketahui bahwa efektivitas pembelajaran ditinjau dari aktivitas belajar mahasiswa tergolong dalam kategori baik. Sebagaimana tampak pada diagram tersebut, bahwa $72 \%$ mahasiswa menyatakan demikian, sedangkan 12 mahasiswa menyatakan aktivitas belajar sangat baik, $13 \%$ mahasiswa menyatakan kurang baik dan 3\% mahasiswa menyatakan sangat kurang baik. 


\section{Hasil Belajar}

Hasil belajar merupakan penilaian terhadap hasil kegiatan belajar pada diri siswa atau peserta didik setelah kegiatan belajarnya. Hasil belajar juga dapat diartikan sebagai hasil yang diperoleh seorang siswa tau peserta didik setelah menjalani kegiatan belajar yang meliputi aspek kognitif, afektif dan psikomotor yang dinyatakan dalam bentuk simbol-simbol, angka, huruf, maupun deskripsi yan dapat mencerminkan kualitas atau pencapain individu dalam proses tertentu (Wahyuningsih, 2020: 65). Selanjutnya, hasil belajar yang dimaksud dalam penelitian ini adalah nilai Ujian Akhir Semester para mahasiswa setelah mengikuti pembelajaran berbasis reseach pada mata kuliah Hikmatut Tasyri', berikut adalah data hasil belajarnya:

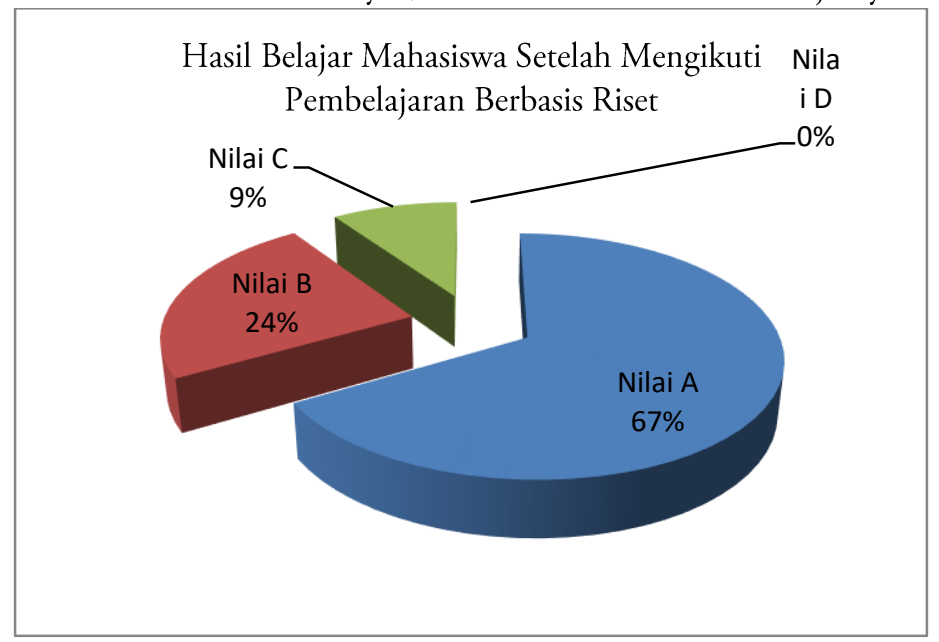

Gambar 5. Hasil Belajar Mahasiswa Setelah Mengikuti Pembelajaran Berbasis Riset

Berdasarkan hasil belajar di atas dapat diketahui bahwa para mahasiswa pada mata kuliah Hikmatut Tasyri' dapat belajar dengan model pembelajaran berbasis riset secara baik sehingga keseluruhan mahasiswa lulus dan memenuhi ketuntasan minimal. Dapat dilihat pada diagram lingkaran di atas, bahwa setelah mengikuti pembelajaran berbasis riset, 67\% mahasiswa dapat menuntaskan hasil belajarnya dengan optimal yakni dengan perolehan predikat nilai A. Selanjutnya 24\% mahasiswa memperoleh predikat nilai B, dan $9 \%$ sisanya memperoleh predikat nilai $\mathrm{C}$, dengan tak seorangpun yang memperoleh nilai pada predikat $\mathrm{D}$ atau tidak lulus (tidak mencapai ketuntasan minimal).

\section{Kesimpulan}

Pelaksanaan pembelajaran berbasis memiliki keunggulan dalam menstimulus peserta didik dalam mengembangkan kemampuan komunikasi, berfikir kritis, memecahkan masalah, berkolaborasi, dan kemampuan menelitinya. Pada penelitian ini, ditemukan bahwa pembelajaran berbasis riset dapat dilaksanakan pada matakuliah Hik'mat al-Tasyri' dengan efektif. Efektivitas pelaksanaan pembelajaran berbasis tentu saja ditentukan oleh keterampilan guru atau dosen sebagai tenaga pendidik yang berperan sebagai fasilitator dan pengelola kelas dalam proses pembelajaran ini. 


\section{DAFTAR PUSTAKA}

Arif Budy Pratama, Jurnal Ilmiah Sebagai Bahan Pembelajaran Berbasis Riset Pada Pendidikan Sarjana Administrasi Negara, Vol. 1, No. 1, September 2017

Fakhrurrazi. (2018). Hakikat Pembelajaran Yang Efektif. Jurnal At-Tafkir Vol. XI No. 1 Juni 2018

Firmadani, Fifit. (2017). Pembelajaran Berbasis Riset Sebagai inovasi Pembelajaran. Prosiding TEP \& PDs. Transformasi Pendidikan Abad 21. Tema:4 Nomor 14, Bulan Mei 2017

Harsono, Ali. (2017). Penerapan Strategi Pembelajaran Komunikatif Untuk Meningkatkan Kemampuan Menulis Laporan Siswa Kelas VA SDN Pajagalan II. Jurnal Autentik, Vol. 1 No.1, Januari 2017

Idah Farida Laily. (2015). Pendekatan Komunikatif Dalam Pembelajaran Bahasa Indonesia Di SD/MI, Vol. 2, 2015

Marasabessy, Apridayani. (2012). Analisis Pengelolaan Pembelajaran yang Dilakukan Oleh Guru yang Sudah Tersertifikasi dan yang Belum Tersertifikasi pada Pembelajaran IPA di Kelas V Sekolah Dasar. Jurnal Penelitian Pendidikan Vol. 13, NO. 1, April 2012

Miftahul Huda (2013). Model-Model Pengajaran Dan Pembelajaran. Yogyakarta: Pustaka Pelajar

Nyoman S Degeng. (2013). Ilmu Pembelajaran: Klasifikasi Variabel Untuk Pengembangan Teori Dan Penelitian. Bandung: Kalam Hidup

Observasi, Di Kampus UIN MALIKI Malang, 10 Februari 2020

Prahmana, Rully C.I. \& Darhim, Yaya S. Kusumah. (2016). Keterampilan Mahasiswa dalam Melakukan Penelitian Pendidikan Matematika Melalui Pembelajaran Berbasis Riset. Beta: Jurnal Tadris Matematika Vo. 9, No. 1 (Mei) 2016

Rangkuti, Ahmad Nizar. (2016). Pembelajaran Berbasis Riset di Perguruan Tinggi. Batusangkar International Conference 7, 15-16 Oktober 2016

Rusman. (2013). Belajar Dan Pembelajaran Berbasis Komputer, Jakarta: Alfabet

Rusman. (2017). Belajar dan Pembelajaran: Berorientasi Standar Proses Pendidikan, Edisi Pertama. Jakarta: Kencana

Slameto. (2015). Pembelajaran Berbasis Riset Mewujudkan Pembelajaran Yang Inspiratif, Satya Widya, Vol. 31, No.2. Desember 2015

Sembiring, M. Gorky. (2008). Mengungkap Rahasia dan Tips Manjur Menjadi Guru Sejati. Yogyakarta: Best Publisher

Setyosari, Punaji. (2014). Menciptakan Pembelajaran yang Efektif dan Berkualitas. Jurnal Inovasi dan Teknologi Pembelajaran, Volume 1, Nomor 1, Oktober 2014

Suyatna, Agus (2017) Membangun Kemampuan Berpikir Kritis, Kreatif, Kolaboratif , Komunikatif Siswa Melalui Proses Pembelajaran. In. Smeinat Nasional Membangun Profesionalisme Guru Pendidikan Dasar dalam Era Global, 9-12 May 2017, Jakarta. 
Undang-Undang Sistem Pendidikan Nasional Nomor 20 Tahun 2003

Wayuningsih, Endang Sri. (2020). Model Pembelajaran Masteri Learning Upaya Peningkatan Keaktivan dan Hasil Belajar Siswa. Yogyakarta: Deepublish

Widiasworo, Erwin. (2018). Cerdas Pengelolaan Kelas. Yogyakarta: Diva Press

Yusuf, Bistari Basuni. (2017). Konsep Dan Indikator Pembelajaran Efektif. Jurnal Kajian Pembelajaran Dan Keilmuan, Vol. 1 NO.2, Oktober 2017 - Maret 2018 
